\title{
Understanding 3D Shapes through STEAM Learning
}

\section{Adib Rifqi Setiawan}

MI NU Tasywiquth Thullab Salafiyyah (TBS) Kudus

Jl. KH. Turaichan Adjhuri No.234, Langgardalem, Kabupaten Kudus, 59315, Indonesia alobatnic@gmail.com

\begin{abstract}
Understanding shapes and space nor their measurement is not only a huge area in mathematics in primary education but also helpful in science, technology, engineering, and art as well. Understanding how 3D shapes are formed is a critical concept in everyday life. The world is built of geometric shapes, the ability to call up 3D shapes in our mind and reason with these images is important for developing spatial awareness. It helps us connect logical intelligence with visual intelligence and gets the two sides working together. It is observed that this concept affects us in the most basic details of our lives. For instance, the building construction, this concept helps us in deciding a look as well as providing proper structures. Technologies such as Magnetic Resonance Imaging scanners (MRIs) and Computed Tomography (CT) scans enable doctors, like dr. Syarofis Siayah, to do their job in a better way. For creating video games like Reza Maulana's favorite i.e. Pro Evolution Soccer (PES), animations like 2NE1's MV "Hate You", and much more. As not everything is easy and understandable, understanding 3D shapes out of 2D nets is no exception. Inspired by chitchatting with Fenny Roshayanti on August 21, 2019 in UPGRIS then Irma Rahma Suwarma on November 24 2019, in UPI, what sparked my STEM (and STEAM) fascination, I implements STEAM (Science, Technology, Engineering and Applied Mathematics)-more focus on Applied Mathematics-at my Mathematics Learning in MI NU Tasywiquth Thullab Salafiyyah (TBS) Kudus during this boring era-I mean distance learning due Pandemic COVID-19-20. To implement this model for Primary Education, I persuades students to make Automated Teller Machine (ATM) or Cashpoint and Locker with Password Lock, both from cardboard. Based on our activities, they are an effective tool for identifying visual 2D information to developing 3D shapes. There are four different 3D shapes made: cube, rectangular cuboid, triangular prism, and cylinder, made of two different 2D shapes: square and rectangle. When they learn to use 3D shapes they also learn to think logical. When thinking logically many difficult problems can be erased and simple solutions can be found. It helps us understand specific phenomena and in uplifting the quality of life.
\end{abstract}

Keywords: Applied Mathematics, Mathematics Learning, Primary Education, STEAM, 